\title{
Istraživanja strukture sastojine u šumama hrasta crnike (Quercus ilex L.) na pokusnim plohama u Hrvatskoj
}

\author{
Damir Barčić, Tomislav Dubravac, Mario Ančić, Željko Španjol, Petar Ćurić
}

\begin{abstract}
Nacrtak-Abstract
Uloga šuma hrasta crnike nije primarno gospodarska, iako djelomično može biti (ogrjevno drvo, biomasa), ali danas u okolnostima klimatskih promjena izraženija je njihova ekološka $i$ socijalna uloga, posebno zato što prevladavaju šume niskoga uzgojnoga oblika (panjače). Površina uređajnoga razreda panjača hrasta crnike u Republici Hrvatskoj iznosi 21 216,63 ha, od toga je 8351,79 ha u redovitom gospodarenju poduzeća Hrvatske šume d.o.o. Površina od 12 740,18 ha nalazi se u šumoposjedničkim šumama. Zajedničko je obilježje panjača hrasta crnike izostanak bilo kakvih uzgojnih radova u mladosti i tijekom njihova razvoja, premda su u panjačama propisani šumskouzgojni radovi na čišćenju i prorjeđivanju te na obnovi. Budući da su prepuštene spontanu razvoju, razvio se čitav spektar, od onih najkvalitetnijih s relativno visokom drvnom zalihom dobro sklopljenih i suvislo obraslih sastojina pa do onih nekvalitetnih, razbijena sklopa, sa sitnim $i$ kvalitetno lošim stablima male drone zalihe. Istraživanjem su obuhvaćene samo plohe u okviru međunarodnoga projekta »Man and Biosphere«-MAB (Čovjek i biosfera), plohe Šumarskoga fakulteta te plohe Hrvatskoga šumarskoga instituta. Strukturna istraživanja radila su se u crnikovim šumama i uspoređivana su na trajnim pokusnim plohama s otoka Raba, Brijuna i otoka Mljeta (TPP br. 36, br. 56 i 57, br. 37). Na trajnim pokusnim plohama izoliranima od antropogenoga utjecaja u tijeku su progresivni sukcescijski procesi, iako je zabilježen intenzivan utjecaj divljači na Rabu i na Cresu, što će uvjetovati problem obnove. Sastojine poprimaju izgled jednodobne sastojine, stabilne su i buduća istraživanja trebala bi pratiti daljnju dinamiku razvoja sastojine. Eventualni poremećaji mogli bi biti izazvani ponajviše požarom.
\end{abstract}

Ključne riječi: panjača crnike, monitoring ploha, eumediteran, konverzija, dinamika razvoja

"Mediteransko šumsko gospodarstvo čini zaseban dio našega šumarstva i po trajanju ophođenja, naročito za lišćare i po svojim proizvodima i po odnosu prema poljoprivrednim kulturama. Šuma u Mediteranu ima pored ostalih i ove dvije osobine: ona je redovno orijetka u etaži glavne sastojine, što znači da se mora obratiti pažnja donjoj, prizemnoj sastojini i vrlo često se javlja na malim površinama, u skupinama ili je isprepletena s poljopriorednim kulturama.»

Dr. sc. Josip Balen (1937)

\section{Uvod - Introduction}

Šume hrasta crnike u Hrvatskoj vrijedan su dio sredozemnih šuma krškoga područja. Njihova uloga nije primarno gospodarska, iako djelomično može biti (ogrjevno drvo, biomasa), ali danas u okolnostima klimatskih promjena (Houghton i dr. 2001,
Ogaya i Peńuelas 2003) izraženija je njihova ekološka i socijalna uloga. Područja u kojima rastu šume hrasta crnike nose obilježje rane naseljenosti i intenzivnoga utjecaja stanovništva te je stoga zamjetan, a na pojedinim dijelovima i presudan utjecaj čovjeka (Plieninger i dr. 2004). Od nekadašnjih kvalitetnih šuma hrasta crnike visokoga uzgojnoga oblika da- 
nas su to uglavnom sastojine uređajnoga razreda panjača te degradirani i devastirani oblici od makija, gariga do kamenjarskih površina. Takva degradirana područja većinom naseljava alepski bor, koji ima značajnu i nezamjenjivu pionirsku ulogu u širenju na degradirane površine, ali i u zadržavanju edafskih uvjeta za mogući povratak autohtone klimatskozonske vegetacije listača.

Iz Šumskogospodarske osnove područja (ŠGOP, 2016-2025) vidi se da ukupna površina uređajnoga razreda panjača hrasta crnike u Republici Hrvatskoj iznosi 21 216,63 ha, od toga je 8351,79 ha u redovitom gospodarenju poduzeća Hrvatske šume d.o.o. Zagreb. Površina od 12 740,18 ha nalazi se u privatnim šumama, dok površinom od 124,66 ha gospodare ostali pravni subjekti. Dakle, relativno se mali udio površine panjača hrasta crnike (39 \%) nalazi u redovitom gospodarenju Hrvatskih šuma d.o.o. Zagreb. Rasprostranjenost uređajnoga razreda hrasta crnike $u$ Republici Hrvatskoj, s obzirom na strukturu vlasništva (Hrvatske šume d.o.o. i šumoposjedničke šume), razvidna je na slici 1, a u tablici 1 razvidna je zastupljenost po upravama šuma podružnicama (UŠP). Iz tablice 1 razvidno je kako se najveći udio uređajnoga razreda panjača hrasta crnike površinom (Hrvatske šume d.o.o.) nalazi u Buzetu (78 \%), Senju (19\%), Splitu (3\%), drvne zalihe najviše je u Buzetu (68 \%), zatim u Senju (30 \%), u Splitu (2\%), prirasta je najviše u Buzetu (62 \%), zatim u Senju (37\%), a najmanje u Splitu (1\%). Kod privatnih je šuma drugačiji omjer. Najviše površina nalazi se u Splitu (50 \%), Buzetu (39\%), a najmanje u Senju (11 \%). Drvne je zalihe najviše u Buzetu (51 \%), Splitu (37\%), u Senju $(12 \%)$, prirasta je najviše u Buzetu (53\%), Splitu $(35 \%)$ i u Senju (12\%).

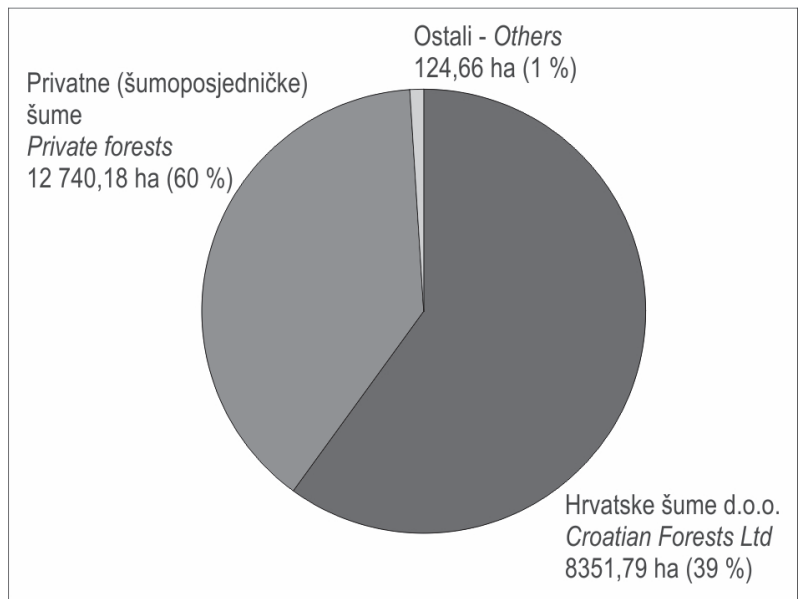

Slika 1. Površina uređajnoga razreda panjača šuma hrasta crnike u Hrvatskoj prema strukturi vlasništva (Izvor: ŠGOP 2016-2025)

Fig. 1 Area of holm oak coppice management class in Croatia according to ownership structure

\section{Pregled i problematika dosadašnjih istraživanja - Review and problems of previous research}

Zajedničko obilježje većine panjača, pa tako i panjača hrasta crnike, jest izostanak uzgojnih radova u mladosti i tijekom njihova razvoja, premda su u panjačama propisani šumskouzgojni radovi na čišćenju i prorjeđivanju te na obnovi (Dubravac i Barčić 2017). Budući da su prepuštene spontanomu razvoju, razvio se čitav spektar, od onih najkvalitetnijih s relativno visokom drvnom zalihom dobro sklopljenih i suvislo obraslih sastojina pa do onih nekvalitetnih,

Tablica 1. Struktura uređajnoga razreda panjača hrasta crnike u Hrvatskoj po upravama šuma podružnicama i strukturi vlasništva (površina, drvna zaliha i prirast)

Table 1 Stand structure of the holm oak coppice management class in Croatia by Forest Administration (FA) and ownership structure (area, wood stock and increment)

\begin{tabular}{|c|c|c|c|c|c|c|}
\hline \multicolumn{4}{|c|}{ Hrvatske šume d.o.o. - Hrvatske šume Ltd } & \multicolumn{3}{|c|}{ Privatne šume - Private forests } \\
\hline $\begin{array}{l}\text { UŠP } \\
F A\end{array}$ & $\begin{array}{l}\text { Površina, ha } \\
\text { Area, ha }\end{array}$ & $\begin{array}{l}\text { Drvna zaliha, } \mathrm{m}^{3} \\
\text { Wood stock, } \mathrm{m}^{3}\end{array}$ & $\begin{array}{c}\text { Prirast, } \mathrm{m}^{3} \\
\text { Increment, } m^{3}\end{array}$ & $\begin{array}{l}\text { Površina, ha } \\
\text { Area, ha }\end{array}$ & $\begin{array}{l}\text { Drvna zaliha, } \mathrm{m}^{3} \\
\text { Wood stock, } \mathrm{m}^{3}\end{array}$ & $\begin{array}{c}\text { Prirast, } \mathrm{m}^{3} \\
\text { Increment, } m^{3}\end{array}$ \\
\hline Senj & 1617,41 & 137599 & 4707 & 1373,60 & 70565 & 2030 \\
\hline Buzet & 6537,45 & 308747 & 7902 & 4964,06 & 304272 & 8863 \\
\hline Split & 196,93 & 8815 & 221 & 6402,52 & 217176 & 5809 \\
\hline Ukupno - Total & 8351,79 & 455161 & 12830 & 12740,18 & 592013 & 16702 \\
\hline \multicolumn{4}{|c|}{ ostali korisnici u RH - RC other users } & \multicolumn{3}{|c|}{ Ukupno - Altogether } \\
\hline $\begin{array}{l}\text { UŠP } \\
F A\end{array}$ & $\begin{array}{l}\text { Površina, ha } \\
\text { Area, ha }\end{array}$ & $\begin{array}{l}\text { Drvna zaliha, } \mathrm{m}^{3} \\
\text { Wood stock, } \mathrm{m}^{3}\end{array}$ & $\begin{array}{c}\text { Prirast, } \mathrm{m}^{3} \\
\text { Increment, } m^{3}\end{array}$ & $\begin{array}{l}\text { Površina, ha } \\
\text { Area, ha }\end{array}$ & $\begin{array}{l}\text { Drvna zaliha, } \mathrm{m}^{3} \\
\text { Wood stock, } \mathrm{m}^{3}\end{array}$ & $\begin{array}{c}\text { Prirast, } \mathrm{m}^{3} \\
\text { Increment, } \mathrm{m}^{3}\end{array}$ \\
\hline Senj & 63,64 & 5226 & 61 & 3054,65 & 213390 & 6798 \\
\hline Buzet & 37,91 & 6088 & 119 & 11539,42 & 619107 & 16884 \\
\hline Split & 23,11 & 2980 & 97 & 6622,56 & 228971 & 6127 \\
\hline Ukupno - Total & 124,66 & 14294 & 277 & 21216,63 & 1061468 & 29809 \\
\hline
\end{tabular}


razbijena sklopa, s kržljavim i kvalitetno lošim stablima male drvne zalihe. Treba naglasiti da je panjača degradirana sastojina u vrlo povoljnim stanišnim uvjetima, pa se prema tome pri konverziji panjača mora zadržati postojeći edafski potencijal staništa. S obzirom na navedene činjenice o strukturi panjača i kakvoći njihova staništa za cilj gospodarenja većine panjača u državnim se šumama uzima njihovo prevođenje u visoki uzgojni oblik, odnosno panjače bi trebalo obnavljati prirodnim putem po načelu oplodnih sječa.

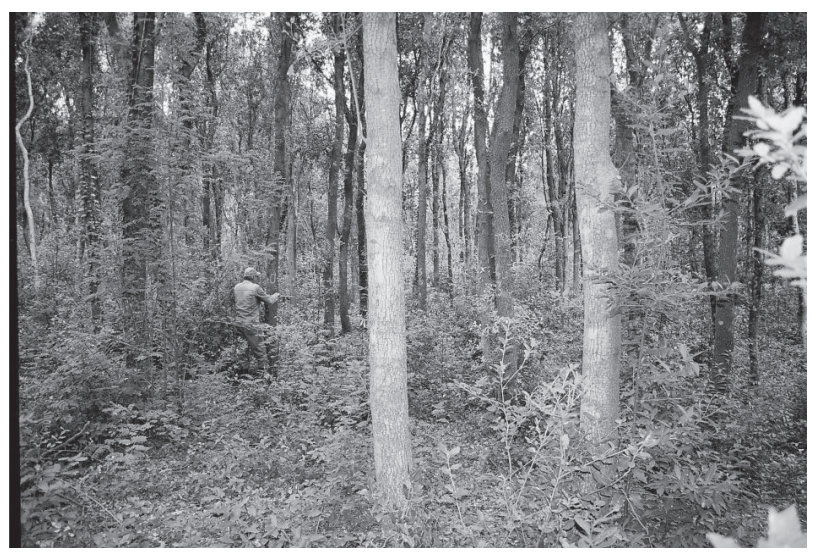

Slika 2. Panjača crnike prije oplodne sječe (foto: T. Dubravac) Fig. 2 Holm oak coppice before shelterwood system (Photo: T. Dubravac)

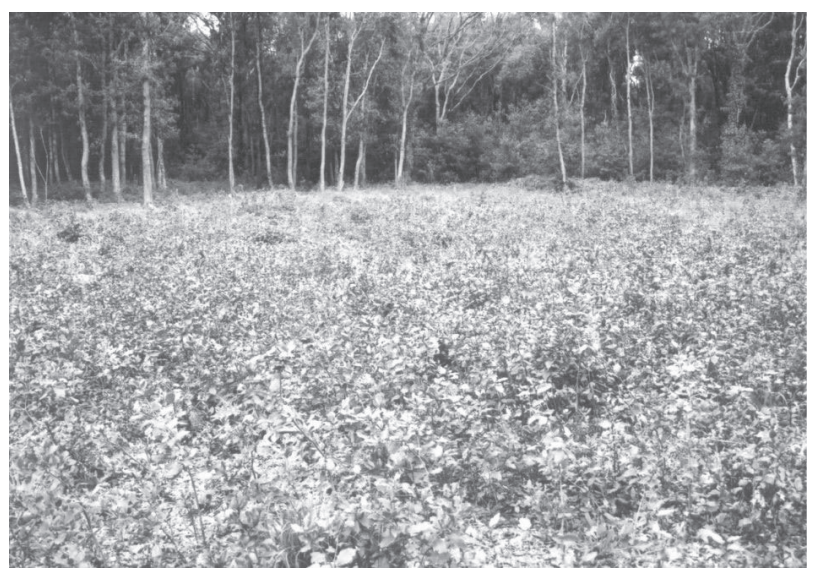

Slika 3. Mlada sjemenjača nakon oplodne sječe (foto: T. Dubravac)

Fig. 3 Young high forest after shelterwood system (Photo: T. Dubravac)

U Hrvatskoj su vrlo rijetke i slabo očuvane crnikove šume visokoga uzgojnoga oblika. Uglavnom je riječ o devastiranim šumama tijekom stoljeća i šumama niskoga uzgojnoga oblika (panjačama, maki- jama). U prvom redu posebno su radi dugotrajnih istraživanja vrijedne šume na otoku Rabu. Šuma Kalifront ili Zeleni rt (Capo fronte, Caput frondis), kako je spominje Brusić (1926), najznačajnija je šuma na otoku. Površina joj je 1266,86 ha, od toga su 1164,30 ha gospodarske šume, a 106,51 ha odnosi se na šumu s posebnom namjenom - posebni rezervat šumske vegetacije Dundo (Španjol 1995). Šuma Kalifront od davnina je bila opterećena pravom služnosti kojim su Rabljani smjeli sjeći »malu šumu« (veliki vrijes, planiku, zeleniku i dr.) bez naknade. Prva je gospodarska osnova (1894) propisala i način gospodarenja koji je pogodovao više sporednim vrstama nego hrastu crniki (Rauš i Vukelić 1994). Ophodnja za crniku bila je propisana na 40 godina, a za ostale vrste na 10 godina. Radi toga je šuma podijeljenja na 20 sječina, površine 50 ha svaka. Tako se svake godine sjeklo 50 ha golom sječom. Takvim načinom sječe glavna vrsta crnika postupno nestaje, panjevi iz kojih tjeraju izbojci stare, gube vitalnost i propadaju, a cijela šuma postupno ide u smjeru devastacije i degradacije (Matić i Rauš 1986). Petračić (1938) navodi da je $\mathrm{u}$ toj šumi ophodnja za glavnu vrstu hrast crniku 20 godina, a za sve podređene vrste 10 godina. No prilikom sječe ostavlja se na sječini određen broj neposječenih stabala crnike. To su buduća nadstojna stabla (pričuvci) koja se sijeku u ophodnji od 40 godina.

Šurić (1933) navodi o šumi Dundo u povodu izrade gospodarske osnove da je stara osnova iz 1906. godine propisala uzgajanje srednje šume, ophodnju za podstojno drveće od 15 godina i za nadstojno 120 godina. Posebni rezervat šumske vegetacije Dundo zakonom je zaštićen 1949. godine. Danas je površina posebnoga rezervata 101,08 ha (Javna ustanova »Priroda« Primorsko-goranske županije 2020).

Uređajni razred panjača hrasta crnike kojima gospodare Hrvatske šume d.o.o. Zagreb zauzimaju 8351,79 ha površine (ŠGOP 2016-2025). U tim panjačama nakon ukidanja čistih sječa (Pravilnik o uređivanju šuma, Narodne novine, 52/1994) propisana je ophodnja od 80 godina. S obzirom na to da sjeme hrasta crnike rađa svake godine, jačim ili slabijim intenzitetom, te na potvrđenu spoznaju da su panjače degradirane sastojine na kvalitetnim staništima, njima se može gospodariti. Sukladno Pravilniku o uređivanju šuma i uzimajući u obzir potrajno gospodarenje kao temeljni postulat hrvatskoga šumarstva, gospodarske se panjače trebaju obnavljati po načelima oplodnih sječa. Tako bi se pokušao ostvariti cilj, a to su stabilne, dobro očuvane i proizvodne sastojine visokoga uzgojnoga oblika, odnosno šume sjemenjače. Za praksu će to biti velik stručni postu- 
pak i posebno velik izdatak zbog povećanih troškova. Već duže vremena sadašnje stanje u praksi upućuje na činjenicu da takvi radovi izostaju jer se radi o velikim troškovima (Krejči i Dubravac 2000, 2004), a i zahtjevnim stručnim zahvatima. Stoga bi bilo potrebno temeljem znanstvenih i stručnih analiza dati i drugačije smjernice jer je upitno mora li se i može li se konverzija uzgojnoga oblika uvijek provesti.

Mnogo prije nego što je donesen navedeni propis 1994. godine, Piškorić (1963), Šafar (1963), Šafar i Dereta (1968), Rauš i Matić (1984), Matić $(1985,1987)$ upozorili su na potrebu i mogućnost racionalnijega načina gospodarenja sastojinama hrasta crnike radi povećanja stabilnosti i vitalnosti tih sastojina. Pravilnik o uređivanju šuma (NN 140/05, NN 82/06) u članku 24. govori o cilju gospodarenja za ophodnju glavne vrste u kojoj propisana ophodnja hrasta crnike od 140 godina kao »donja granica ophodnje u panjačama koje se prirodnim putem prevode $\mathrm{u}$ sjemenjače, smanjuje se za $30 \%$ od utvrđenih donjih granica ophodnje«. $\mathrm{U}$ drugim sredozemnim zemljama gospodarenje crnikovim panjačama provodi se kratkim ophodnjama od 30 godina ili manje, primjerice $\mathrm{u}$ Italiji nakon 18 20 godina, na jugu Francuske 15-20 godina, u Kataloniji se primjenjuju selektivne sječe u intervalima od 20 do 30 godina za ogrjevno drvo (Ibañez i dr. 1999). Za sastojine visokoga uzgojnoga oblika navodi se ophodnja između 100 i 130 godina (Bernetti 1995), dok se za panjače na Sardiniji u Italiji primjenjuju oplodne sječe gdje se nakon sječe ostavlja oko 150 stabala po hektaru (Vacca i dr. 2016). Svakako da je u panjači broj biljaka iz panja (svih vrsta) od 270000 do preko 400000 velik biološki problem, a time i financijski s obzirom na učestalost (svakih 2-3 godine) njege da bi se sačuvalo 70000 do 90000 biljaka iz sjemena hrasta crnike, dok se biljke ne izdignu agresivnoj konkurenciji pratilica iz panja.

Tim su se problemom uspješno bavili i radove objavili Dubravac i Krejči (2001), Krejči i Dubravac (2000, 2004), Dubravac i Dekanić (2011), Dubravac i dr. (2018). Tijekom višegodišnjih sustavnih istraživanja praćen je razvoj ponika i pomlatka u sačuvanoj panjači hrasta crnike (Fraxino orni-Quercetum ilicis H-ić 1956/1958) primjenom načela oplodnih sječa. One su se pokazale uspješne uz činjenicu da pojava i preživljavanje mladoga naraštaja hrasta crnike iz sjemena zahtijeva učinkovite i pravodobne prorede te višekratnu njegu. Zastrtost tla krošnjama, prema autorima, veća od $85 \%$ ograničava razvoj mladoga naraštaja hrasta crnike. Autori preporučuju da pomladno razdoblje, uz pravilno vođenje oplodnih sječa, pravilnu i adekvatnu njegu sastojine, praćenjem godina dobroga uroda sjemenom, ne treba biti duže od 10 godina. Kada se objašnjava uspjeh na obnovi i konverziji crnikove panjače, treba napomenuti da se istraživano područje nalazi kraj Pule na bonitetno iznimno kvalitetnom staništu gdje je tip tla ilimerizirana crvenica neutralne reakcije $\mathrm{u}$ humusnom horizontu. Takve klimatskozonske sastojine hrasta crnike stabilni su ekosustavi koji se relativno lako odupiru negativnim biotskim i abiotskim čimbenicima te osim svoje gospodarske uloge imaju višestruku vrijednost u pružanju općekorisnih funkcija šuma. S obzirom na klimatske i geomorfološke uvjete na tom području, njezina je uloga osobito važna u smanjenju erozijskih procesa i zaštiti tla, vode, mikroklime, biološke raznolikosti i vrijednosti krajolika. Budući da je to područje izloženo čestim požarima, uloga hrasta crnike kao vrste otpornije na požare dolazi do punoga izražaja. Navedene višenamjenske uloge idu u prilog potrebi značajnijega istraživanja hrasta crnike radi očuvanja genofonda, genetske i biološke raznolikosti i potrajnosti sredozemnih šumskih ekosustava. Također, imajući na umu buduće gospodarenje, potrebno je razmotriti i sadašnje propise te znanstveno i stručno utvrditi treba li sve panjače crnike prevoditi u viši uzgojni oblik ili je u određenim stanišnim uvjetima moguće kvalitetno i opravdano gospodariti panjačama.

\section{Materijal i metode Material and methods}

Za izradu lokalne tarife poslužila je terenski izmjerena visina. Lokalni obujamni nizovi (tarife) za vrste u sastojini izračunate su pomoću Schumacher-Hallove jednadžbe:

$V=b_{0} \times d^{b_{1}} \times h^{b_{2}} \times f$

Obujam ostalih vrsta drveća na plohi za koje ne postoje parametri izračunat je po istoj jednadžbi supstituirajuću parametre hrasta crnike.

\begin{tabular}{|c|c|c|c|c|}
\hline \multirow{2}{*}{$\begin{array}{c}\text { Quercus } \\
\text { ilex L. }\end{array}$} & $b_{0}$ & $b_{1}$ & $b_{2}$ & $f$ \\
\cline { 2 - 5 } & 0,000096 & 1,821 & 0,759 & 1 \\
\hline
\end{tabular}

Dobivene vrijednosti visine izjednačene su Mihajlovljevom funkcijom:

$h=b_{o} \times e \frac{-b_{1}}{d}+1,30$

gdje su:

$b_{0^{\prime}} b_{1}$ parametri procjenjeni metodom najmanjih kvadrata

e baza prirodnoga logaritma

d prsni promjer stabla. 
Metoda najmanjega kvadrata koristi se kako bi se minimiziralo kvadratno odstupanje izjednačenih od izmjerenih vrijednosti.

\subsection{Područje istraživanja - Area of research}

Istraživanjem su obuhvaćene samo plohe u okviru međunarodnoga projekta »Man and Biosphere «MAB (Čovjek i biosfera), plohe Šumarskoga fakulteta (osnivane istraživanjima Rauša i Matića, Španjola i Barčića) te plohe Hrvatskoga šumarskoga instituta (osnivane istraživanjima Krejčija i Dubravca) prikazane na slici 4 .

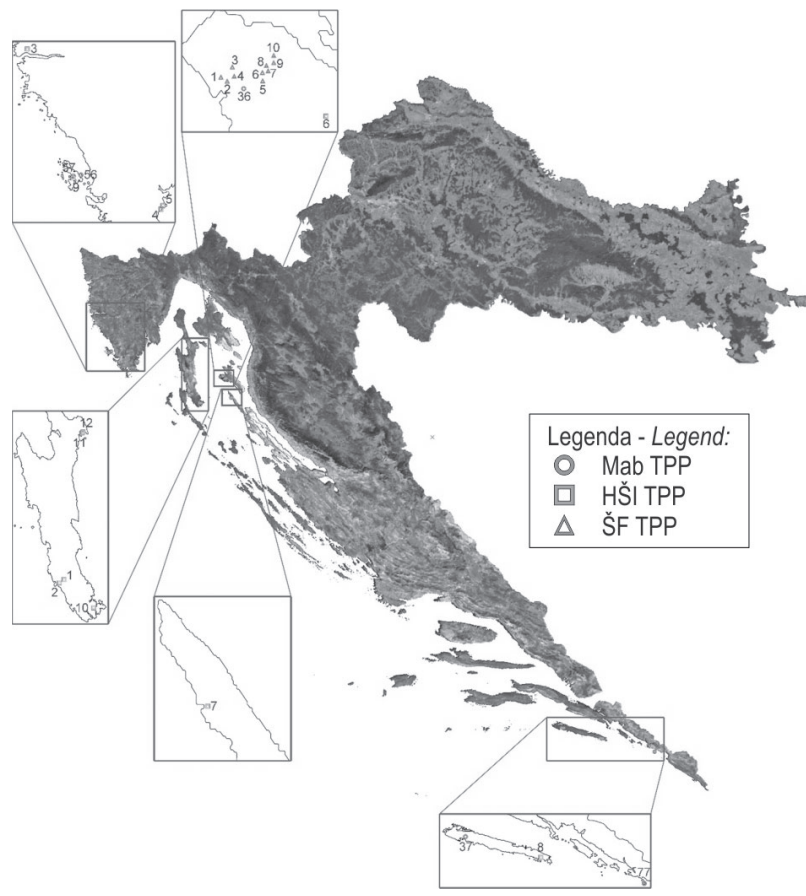

Slika 4. Trajne pokusne plohe (MAB, Šumarski fakultet i Hrvatski šumarski institut)

Fig. 4 Permanent experimental plots (MAB, Faculty of Forestry and Croatian Forestry Institute)

\section{Rezultati istraživanja - Research results}

Strukturna istraživanja $\mathrm{u}$ crnikovim šumama mogu se usporediti na trajnim pokusnim plohama s otoka Raba, Brijuna i otoka Mljeta (TPP br. 36, br. 56 i 57, br. 37).

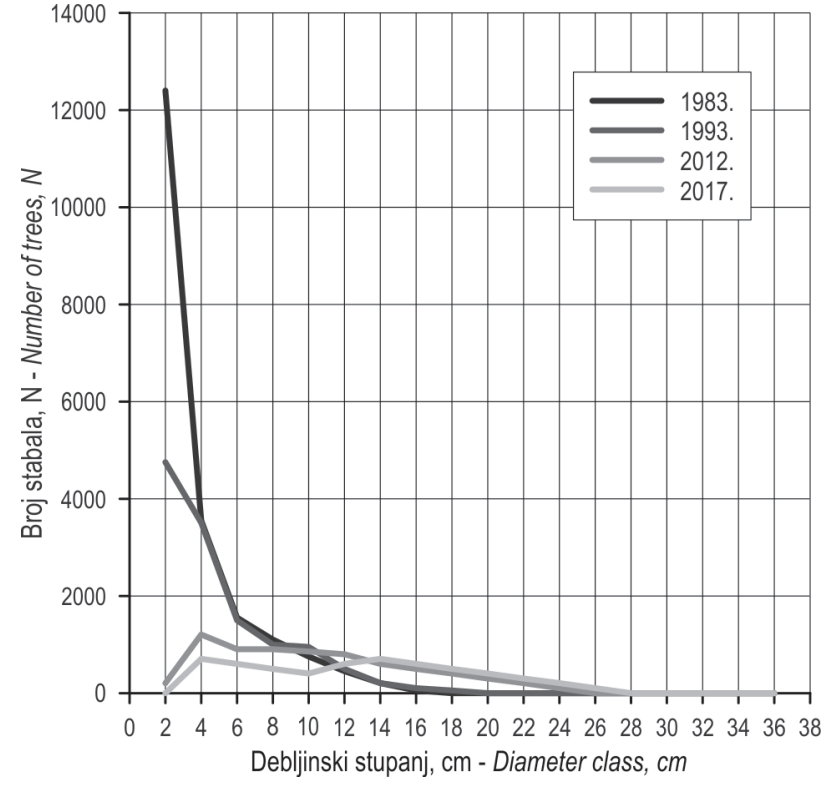

Slika 5. Dinamika i praćenje stanja na trajnoj pokusnoj plohi 36 na Rabu

Fig. 5 Dynamics and monitoring of permanent experimental plot 36 on the island of Rab

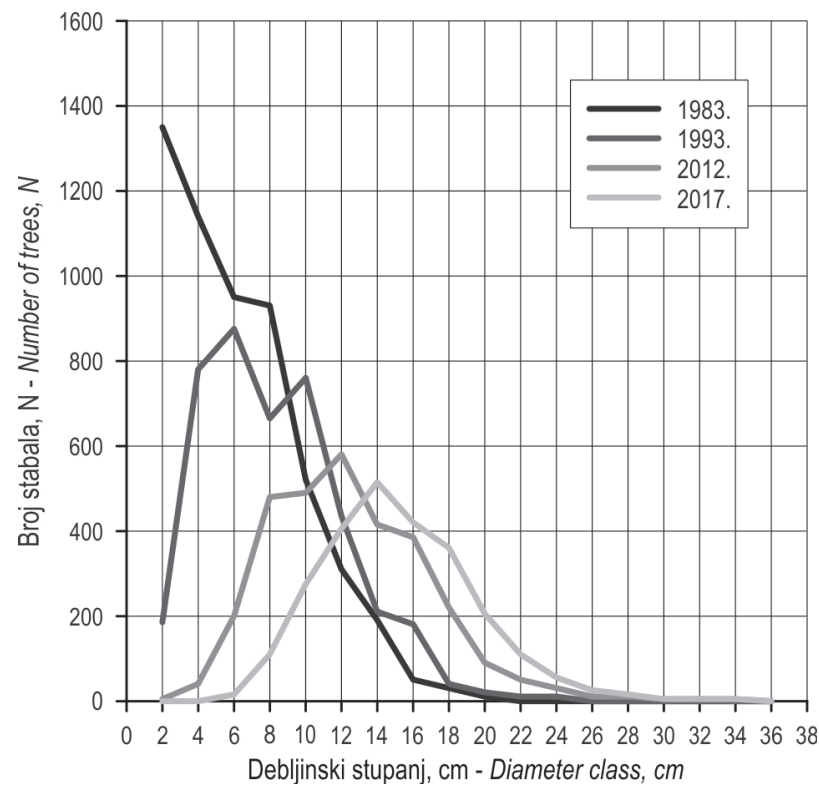

Slika 6. Broj stabala hrasta crnike na trajnoj pokusnoj plohi 36 na Rabu

Fig. 6 Number of holm oak trees on permanent experimental plot 36 on the island of Rab 


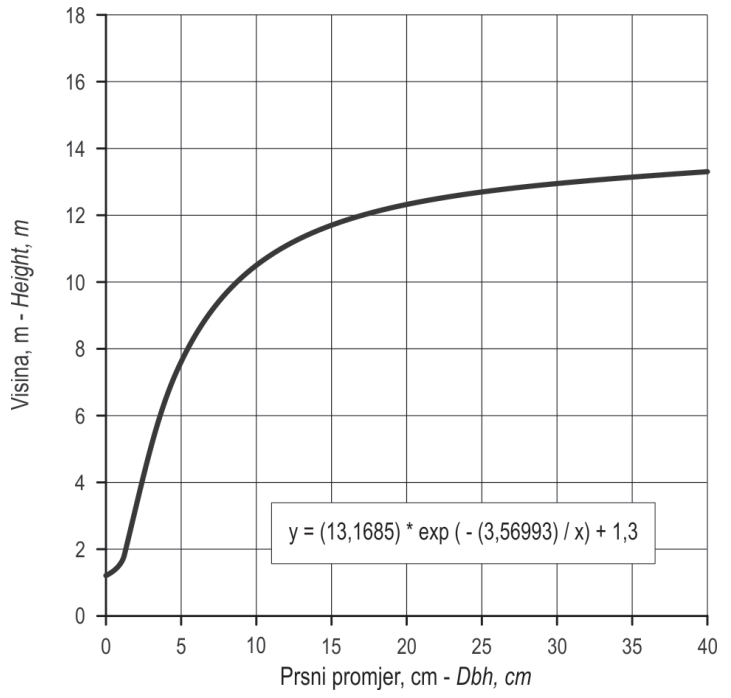

Slika 7. Visinska krivulja hrasta crnike na trajnoj pokusnoj plohi 36 na Rabu

Fig. 7 Height curve of holm oak on permanent experimental plot 36 on the island of Rab

Usporedbom s drugim trajnim pokusnim plohama na otocima Brijuni i Mljet, na kojima se također nalazi zajednica Fraxino orni-Quercetum ilicis $\mathrm{H}$-ić, dobiva se šira slika o sukcesiji te zajednice. S obzirom na to da za trajnu pokusnu plohu br. 57, koja se nalazi na Brijunima, postoji samo jedna izmjera, primarno se usporedba odnosi na izmjere trajne pokusne plohe br. 36 na Rabu i br. 37 na Mljetu. Kako navode Barčić, Španjol i Antonić (2000), sastojina je na Mljetu 28 godina starija od sastojine na Rabu. Danas TPP na Brijunima ima 137 godina, TPP na Mljetu 103 godine, a TPP na Rabu 75 godina.

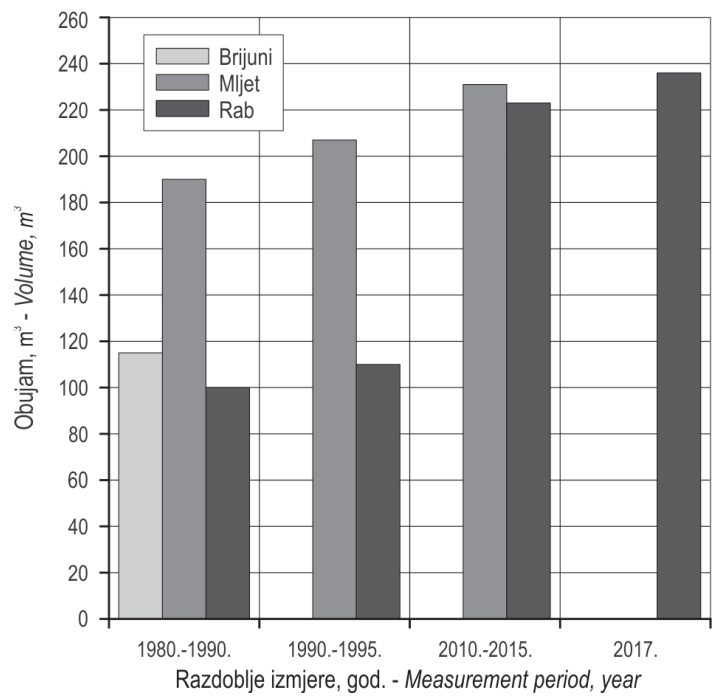

Slika 8. Usporedba trajnih ploha na Brijunima, Rabu i Mljetu Fig. 8 Comparison of permanent experimental plots on the islands of Brijuni, Rab and Mljet
Slike 8 i 9 pokazuju kretanje obujma (drvne zalihe) na trajnim pokusnim plohama. Nagli porast obujma u razdoblju od dvadeset godina na Rabu (1993-2013) vezan je uz razvojnu fazu sastojine, tj. otvorenost sklopa sastojine jer se izdignuo sloj drveća s dominantnom crnikom.

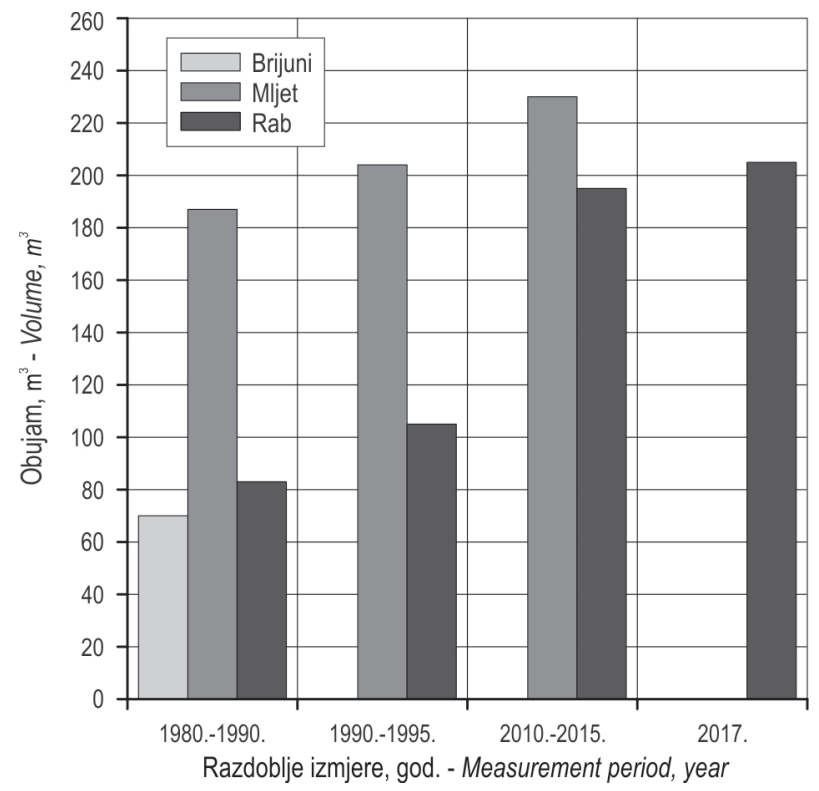

Slika 9. Usporedba obujma hrasta crnike na trajnim pokusnim plohama

Fig. 9 Comparison of holm oak volume on permanent experimental plots

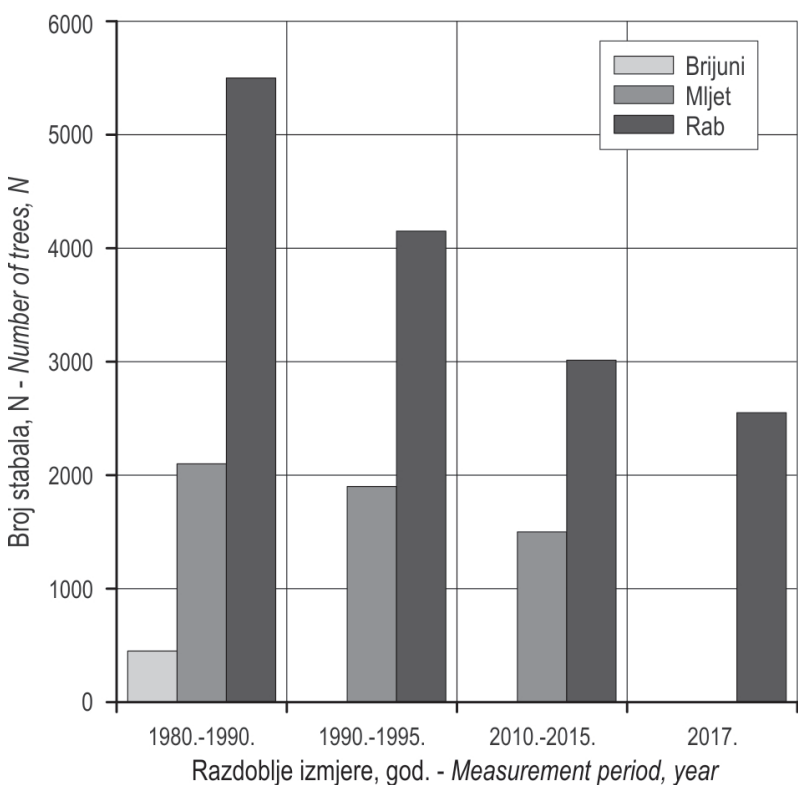

Slika 10. Broj stabala hrasta crnike na Brijunima, Mljetu i Rabu Fig. 10 Number of holm oak trees on Brijuni, Mljet and Rab 
Tablica 4 prikazuje rast i razvoj hrasta crnike na pokusnim plohama tijekom višegodišnjih istraživanja (1997-2017).

Tablica 2. Osnovni podaci o istraživanim trajnim pokusnim plohama Hrvatskoga šumarskoga instituta Table 2 General data on experimental plots of Croatian Forestry Institute

\begin{tabular}{|c|c|c|c|c|c|c|c|c|}
\hline $\begin{array}{c}\text { Broj plohe } \\
\text { Number of } \\
\text { plot }\end{array}$ & $\begin{array}{c}\text { Godina osnivanja } \\
\text { Year of } \\
\text { establishment }\end{array}$ & $\begin{array}{c}\text { Starost plohe } \\
\text { Age of plot }\end{array}$ & $\begin{array}{c}\text { Uprava šuma } \\
\text { Forest } \\
\text { administration }\end{array}$ & $\begin{array}{c}\text { Šumarija } \\
\text { Forest } \\
\text { management }\end{array}$ & $\begin{array}{c}\text { Gospodarska } \\
\text { jedinica } \\
\text { Management unit }\end{array}$ & $\begin{array}{c}\text { Odjel/odsjek } \\
\text { Department }\end{array}$ & $\begin{array}{c}\text { Oblk plohe } \\
\text { Plot form }\end{array}$ & $\begin{array}{c}\text { Površina } \\
\text { plohe, ha } \\
\text { Plot area, ha }\end{array}$ \\
\hline 1 & 1996. & 46 & Buzet & Cres-Lošinj & Punta Križa & $4 a$ & $50 \times 50 \mathrm{~m}$ & 0,25 \\
\hline 2 & 1996. & 42 & Buzet & Cres-Lošinj & Punta Križa & $5 \mathrm{~b}$ & $50 \times 50 \mathrm{~m}$ & 0,25 \\
\hline 3 & 1997. & 28 & Buzet & Poreč & Lim & $5 \mathrm{a}$ & $20 \times 20 \mathrm{~m}$ & 0,04 \\
\hline 4 & 1997. & 51 & Buzet & Pula & Magran-Cuf & $83 \mathrm{a}$ & $50 \times 50 \mathrm{~m}$ & 0,25 \\
\hline 5 & 1997. & 55 & Buzet & Pula & Magran-Cuf & $80 \mathrm{~b}$ & $50 \times 50 \mathrm{~m}$ & 0,25 \\
\hline 6 & 1997. & 54 & Senj & Rab & Kalifront & 36 & $30 \times 50 \mathrm{~m}$ & 0,15 \\
\hline 7 & 1997. & 42 & Senj & Pag & Novalja & $6 a$ & $30 \times 50 \mathrm{~m}$ & 0,15 \\
\hline 8 & 1998. & 65 & NP Mljet & NP Mljet & NP Mljet & $47 b$ & $50 \times 50 \mathrm{~m}$ & 0,25 \\
\hline 9 & 1998. & 97 & NP Mljet & NP Brijuni & NP Brijuni & - & $50 \times 50 \mathrm{~m}$ & 0,25 \\
\hline 10 & 2000. & 42 & Buzet & Cres-Lošinj & Punta Križa & $24 \mathrm{c}$ & $50 \times 50 \mathrm{~m}$ & 0,25 \\
\hline 11 & 2017. & 50 & Buzet & Cres-Lošinj & Tramontana & $121 \mathrm{a}$ & $50 \times 50 \mathrm{~m}$ & 0,25 \\
\hline 12 & 2017. & 50 & Buzet & Cres-Lošinj & Tramontana & $121 \mathrm{a}$ & $50 \times 50 \mathrm{~m}$ & 0,25 \\
\hline
\end{tabular}

Tablica 3. Osnovni strukturni podaci pokusnih ploha po broju stabala, temeljnici i drvnoj zalihi

Table 3 General structural data of experimental plots by tree numbers, basal area and growing stock

\begin{tabular}{|c|c|c|c|c|c|c|c|c|c|c|}
\hline \multirow{2}{*}{$\begin{array}{c}\text { Broj plohe } \\
\text { Number of } \\
\text { plot }\end{array}$} & \multirow{2}{*}{$\begin{array}{c}\text { Starost } \\
\text { plohe } \\
\text { Age of plot }\end{array}$} & \multicolumn{3}{|c|}{$\begin{array}{l}\text { Broj stabala, N/ha } \\
\text { Tree numbers, N/ha }\end{array}$} & \multicolumn{3}{|c|}{$\begin{array}{l}\text { Temeljnica, } \mathrm{m}^{2} / \mathrm{ha} \\
\text { Basal area, } \mathrm{m}^{2} / \mathrm{ha}\end{array}$} & \multicolumn{3}{|c|}{$\begin{array}{l}\text { Obujam, } \mathrm{m}^{3} / \mathrm{ha} \\
\text { Volume, } \mathrm{m}^{3} / \mathrm{ha}\end{array}$} \\
\hline & & $\begin{array}{c}\text { Crnika } \\
\text { Holm oak }\end{array}$ & $\begin{array}{l}\text { OTB } \\
\text { Other }\end{array}$ & $\begin{array}{c}\text { Ukupno } \\
\text { Total }\end{array}$ & $\begin{array}{c}\text { Crnika } \\
\text { Holm oak }\end{array}$ & $\begin{array}{l}\text { OTB } \\
\text { Other }\end{array}$ & $\begin{array}{c}\text { Ukupno } \\
\text { Total }\end{array}$ & $\begin{array}{c}\text { Crnika } \\
\text { Holm oak }\end{array}$ & $\begin{array}{l}\text { OTB } \\
\text { Other }\end{array}$ & $\begin{array}{c}\text { Ukupno } \\
\text { Total }\end{array}$ \\
\hline 1 & 46 & 3816 & 608 & 4424 & 29,02 & 2,62 & 31,64 & 146,38 & 13,37 & 159,75 \\
\hline 2 & 42 & 2772 & 268 & 3040 & 24,36 & 2,39 & 25,75 & 122,34 & 7,09 & 129,43 \\
\hline 3 & 28 & 3525 & 1575 & 5100 & 19,20 & 5,79 & 24,99 & 82,32 & $24,74-$ & 107,06 \\
\hline 4 & 51 & 1144 & 168 & 1312 & 19,01 & 3,96 & 22,97 & 134,32 & 27,68 & 162,00 \\
\hline 5 & 55 & 2292 & 552 & 2844 & 36,35 & 7,81 & 43,99 & 219,10 & 52,83 & 271,93 \\
\hline 6 & 54 & 2140 & 120 & 2260 & 34,95 & 1,30 & 36,25 & 178,92 & 6,40 & 185,33 \\
\hline 7 & 42 & 2393 & 87 & 2480 & 28,41 & 0,63 & 29,00 & 120,38 & 2,60 & 122,98 \\
\hline 8 & 65 & 1576 & - & 1576 & 31,91 & - & 31,91 & 185,10 & - & 185,10 \\
\hline 9 & 97 & 448 & 152 & 600 & 23,21 & 2,07 & 25,28 & 121,74 & 9,81 & 131,55 \\
\hline 10 & 42 & 1984 & 216 & 2200 & 24,74 & 1,63 & 26,39 & 167,69 & 10,45 & 178,14 \\
\hline 11 & 50 & 1188 & 132 & 1320 & 23,38 & 2,99 & 26,37 & 113,47 & 11,16 & 124,68 \\
\hline 12 & 50 & 852 & 252 & 1104 & 26,81 & 7,44 & 34,30 & 122,72 & 29,69 & 152,42 \\
\hline
\end{tabular}


Tablica 4. Tijek razvoja hrasta crnike iz sjemena po visinskim razredima i godinama izmjere u apsolutnom (N) i postotnom iznosu (\%): 1997-2003, 2008, 2011, 2013, 2014, 2017. godine

Table 4 Holm oak from seed, development according to height classes in measurement years, apsolute (N), relative (\%): 1997-2003, 2008, 2011, 2013, 2014, 2017 year

\begin{tabular}{|c|c|c|c|c|c|c|c|c|c|c|c|c|c|c|}
\hline \multirow{3}{*}{$\begin{array}{l}\text { Godina izmjere } \\
\text { Measurement year }\end{array}$} & \multicolumn{14}{|c|}{$\begin{array}{l}\text { Visinski razredi, } \mathrm{cm} \text { - Broj biljaka, } \mathrm{N}(\%) \\
\text { Height class, } \mathrm{cm} \text { - Number of plants, } \mathrm{N}(\%)\end{array}$} \\
\hline & \multicolumn{2}{|c|}{$<31$} & \multicolumn{2}{|c|}{$31-61$} & \multicolumn{2}{|c|}{$61-131$} & \multicolumn{2}{|c|}{$131-150$} & \multicolumn{2}{|c|}{$151-200$} & \multicolumn{2}{|c|}{$201-250$} & \multicolumn{2}{|c|}{$>251$} \\
\hline & $\mathrm{N}$ & $\%$ & $\mathrm{~N}$ & $\%$ & $\mathrm{~N}$ & $\%$ & $\mathrm{~N}$ & $\%$ & $\mathrm{~N}$ & $\%$ & $\mathrm{~N}$ & $\%$ & $\mathrm{~N}$ & $\%$ \\
\hline 1997. & 83600 & 100 & - & - & - & - & - & - & - & - & - & - & - & - \\
\hline 1998. & 84868 & 98 & 1732 & 2 & - & - & - & - & - & - & - & - & - & - \\
\hline 1999. & 81990 & 90 & 9110 & 10 & - & - & - & - & - & - & - & - & - & - \\
\hline 2000. & 63764 & 76 & 19297 & 23 & 839 & 1 & - & - & - & - & - & - & - & - \\
\hline 2001. & 49135 & 62 & 27738 & 35 & 2377 & 3 & - & - & - & - & - & - & - & - \\
\hline 2002. & 39010 & 47 & 37350 & 45 & 6640 & 8 & - & - & - & - & - & - & - & - \\
\hline 2003. & 33251 & 41 & 39739 & 49 & 8110 & 10 & - & - & - & - & - & - & - & - \\
\hline 2008. & 15575 & 35 & 3560 & 8 & 3560 & 8 & 890 & 2 & 4005 & 9 & 6230 & 14 & 10680 & 24 \\
\hline 2011. & 1073 & 3 & 6077 & 17 & 3575 & 10 & 357 & 1 & 1073 & 3 & 2860 & 8 & 20735 & 58 \\
\hline 2013. & 606 & 2 & 1818 & 6 & 2727 & 9 & 606 & 2 & 1818 & 6 & 4242 & 14 & 18483 & 61 \\
\hline 2014. & - & - & 275 & 1 & 551 & 2 & 551 & 2 & 826 & 3 & 826 & 3 & 24502 & 89 \\
\hline 2017. & - & - & - & - & - & - & - & - & 734 & 2 & 1102 & 3 & 34844 & 95 \\
\hline
\end{tabular}

Također, na pokusnim plohama u crnikovim panjačama na otoku Rabu provedena su istraživanja i prorjeđivanje.

Tablica 5. Struktura sastojine prije prorede

Table 5 Stand structure before thinning

\begin{tabular}{|c|c|c|c|c|c|c|c|c|c|c|c|c|}
\hline \multicolumn{5}{|c|}{ Šumarija: Rab - Forest management: Rab } & \multicolumn{8}{|c|}{ Pokusna ploha: PP1 (prije prorede) - Experimental plot: PP1 (before thinning) } \\
\hline \multicolumn{5}{|c|}{ Gospodarska jedinica: Kalifront - Management unit: Kalifront } & \multicolumn{8}{|c|}{ Površina: $40 \times 12,5 \mathrm{~m}\left(500 \mathrm{~m}^{2}\right)-$ Area: $40 \times 12.5 \mathrm{~m}\left(500 \mathrm{~m}^{2}\right)$} \\
\hline \multicolumn{5}{|c|}{ Odjel/odsjek: $10 \mathrm{~b}$ - Department: $10 \mathrm{~b}$} & \multicolumn{8}{|c|}{ Godina: 10. 10. 2006. - Year: October 10, 2006} \\
\hline \multirow{2}{*}{$\begin{array}{l}\text { Deb. raz., cm } \\
\text { Diam. cl., cm }\end{array}$} & \multicolumn{3}{|c|}{ Quercus ilex } & \multicolumn{3}{|c|}{ Fraxinus ornus } & \multicolumn{3}{|c|}{ Arbutus unedo } & \multicolumn{3}{|c|}{ Ukupno - Total } \\
\hline & $\mathrm{N}$ & G & V & $\mathrm{N}$ & G & $\mathrm{V}$ & $\mathrm{N}$ & G & V & $\mathrm{N}$ & G & V \\
\hline 2 & 1 & 0,001 & 0,002 & 1 & 0,001 & 0,003 & & & & 2 & 0,001 & 0,004 \\
\hline 4 & 1 & 0,001 & 0,004 & 5 & 0,008 & 0,036 & 3 & 0,004 & 0,013 & 9 & 0,013 & 0,053 \\
\hline 6 & 1 & 0,003 & 0,012 & 2 & 0,004 & 0,020 & 2 & 0,005 & 0,017 & 5 & 0,012 & 0,048 \\
\hline 8 & 13 & 0,075 & 0,285 & & & & & & & 13 & 0,075 & 0,285 \\
\hline 10 & 22 & 0,181 & 0,785 & & & & & & & 22 & 0,181 & 0,785 \\
\hline 12 & 37 & 0,425 & 1,961 & & & & & & & 37 & 0,425 & 1,961 \\
\hline 14 & 18 & 0,287 & 1,381 & & & & & & & 18 & 0,287 & 1,381 \\
\hline 16 & 16 & 0,323 & 1,544 & & & & & & & 16 & 0,323 & 1,544 \\
\hline 18 & 8 & 0,195 & 0,961 & & & & & & & 8 & 0,195 & 0,961 \\
\hline 20 & 1 & 0,030 & 0,153 & & & & & & & 1 & 0,030 & 1,153 \\
\hline 22 & 1 & 0,038 & 0,197 & & & & & & & 1 & 0,038 & 0,197 \\
\hline Ukupno - Total & 119 & 1,56 & 7,29 & 8 & 0,01 & 0,06 & 5 & 0,01 & 0,03 & 132 & 1,58 & 7,37 \\
\hline Po ha - Perha & 2380 & 31,17 & 145,72 & 160 & 0,27 & 1,16 & 100 & 0,16 & 0,61 & 2640 & 31,59 & 147,49 \\
\hline \multicolumn{5}{|c|}{ Šumarija: Rab - Forest management: Rab } & \multicolumn{8}{|c|}{ Pokusna ploha: PP1 (etat prorede) - Experimental plot: PP1 (thinning volume) } \\
\hline \multicolumn{5}{|c|}{ Gospodarska jedinica: Kalifront - Management unit: Kalifront } & \multicolumn{8}{|c|}{ Površina: 40 × 12,5 m $\left(500 \mathrm{~m}^{2}\right)$ - Area: $40 \times 12,5 \mathrm{~m}\left(500 \mathrm{~m}^{2}\right)$} \\
\hline \multicolumn{5}{|c|}{ Odjel/odsjek: 10b - Department: 10b } & \multicolumn{8}{|c|}{ Godina: 11. 10. 2006. - Year: October 11, 2006} \\
\hline \multirow{2}{*}{$\begin{array}{l}\text { Deb. raz., cm } \\
\text { Diam. cl., cm }\end{array}$} & \multicolumn{3}{|c|}{ Quercus ilex } & & & & & & & \multicolumn{3}{|c|}{ Ukupno - Total } \\
\hline & $\mathrm{N}$ & G & V & $\mathrm{N}$ & G & V & $\mathrm{N}$ & G & V & $\mathrm{N}$ & G & V \\
\hline 2 & 1 & 0,001 & 0,02 & & & & & & & 1 & 0,001 & 0,02 \\
\hline 4 & 1 & 0,001 & 0,004 & & & & & & & 1 & 0,001 & 0,004 \\
\hline 6 & 1 & 0,003 & 0,012 & & & & & & & 1 & 0,003 & 0,012 \\
\hline 8 & 11 & 0,063 & 0,239 & & & & & & & 11 & 0,063 & 0,239 \\
\hline 10 & 10 & 0,082 & 0,340 & & & & & & & 10 & 0,082 & 0,340 \\
\hline 12 & 12 & 0,146 & 0,668 & & & & & & & 12 & 0,146 & 0,668 \\
\hline 14 & 2 & 0,031 & 0,152 & & & & & & & 2 & 0,031 & 0,152 \\
\hline Ukupno - Total & 38 & 0,33 & 1,42 & & & & & & & 38 & 0,33 & 1,42 \\
\hline Po ha - Per ha & 760 & 6,53 & 28,33 & & & & & & & 760 & 6,53 & 28,33 \\
\hline
\end{tabular}


Pokusna ploha PP1 nalazi se u panjači hrasta crnike koja ima 45 godina. Godine 2006. ona je prorijeđena. Intenzitet je prorede iznosio 19,2 \% drvne zalihe. Iz sastojine su uklonjene jedinke koje ometaju budući razvoj odabranih stabala, a proreda je u potpunosti provedena na glavnoj vrsti drveća (hrast crnika). U tablici 6 vidljivo je povećanje brojnosti svih vrsta drveća na plohi zbog nagloga otvaranja sklopa. Velik broj mladih crnikovih stabala prešao je taksacijsku granicu.

Tablica 6. Struktura sastojine nakon prorede 2006. i 2014. godine Table 6 Stand structure after thinning in 2006 and 2014

\begin{tabular}{|c|c|c|c|c|c|c|c|c|c|c|c|c|}
\hline \multicolumn{5}{|c|}{ Šumarija: Rab - Forest management: Rab } & \multicolumn{8}{|c|}{ Pokusna ploha: PP1 (nakon prorede) - Experimental plot: PP1 (after thinning) } \\
\hline \multicolumn{5}{|c|}{ Gospodarska jedinica: Kalifront - Management unit: Kalifront } & \multicolumn{8}{|c|}{ Površina: $40 \times 12,5 \mathrm{~m}\left(500 \mathrm{~m}^{2}\right)$ - Area: $40 \times 12,5 \mathrm{~m}\left(500 \mathrm{~m}^{2}\right)$} \\
\hline \multicolumn{5}{|c|}{ Odjel/odsjek: 10b - Department: 10b } & \multicolumn{8}{|c|}{ Godina: 10. 10. 2006. - Year: October 10, 2006} \\
\hline \multirow{2}{*}{$\begin{array}{l}\text { Deb. raz., } \mathrm{cm} \\
\text { Diam. cl., } \mathrm{cm}\end{array}$} & \multicolumn{3}{|c|}{ Quercus ilex } & \multicolumn{3}{|c|}{ Fraxinus ornus } & \multicolumn{3}{|c|}{ Arbutus unedo } & \multicolumn{3}{|c|}{ Ukupno - Total } \\
\hline & $\mathrm{N}$ & G & V & $\mathrm{N}$ & G & V & $\mathrm{N}$ & G & V & $\mathrm{N}$ & G & V \\
\hline 2 & & & & 1 & 0,001 & 0,003 & & & & 1 & 0,001 & 0,003 \\
\hline 4 & & & & 5 & 0,008 & 0,036 & 3 & 0,004 & 0,013 & 8 & 0,012 & 0,049 \\
\hline 6 & & & & 2 & 0,004 & 0,020 & 2 & 0,005 & 0,017 & 4 & 0,009 & 0,037 \\
\hline 8 & 2 & 0,011 & 0,046 & & & & & & & 2 & 0,011 & 0,046 \\
\hline 10 & 12 & 0,100 & 0,445 & & & & & & & 12 & 0,100 & 0,445 \\
\hline 12 & 25 & 0,279 & 1,293 & & & & & & & 25 & 0,279 & 1,293 \\
\hline 14 & 16 & 0,256 & 1,229 & & & & & & & 16 & 0,256 & 1,229 \\
\hline 16 & 16 & 0,323 & 1,544 & & & & & & & 16 & 0,323 & 1,544 \\
\hline 18 & 8 & 0,195 & 0,961 & & & & & & & 8 & 0,195 & 0,961 \\
\hline 20 & 1 & 0,030 & 0,153 & & & & & & & 1 & 0,030 & 0,153 \\
\hline 22 & 1 & 0,038 & 0,197 & & & & & & & 1 & 0,038 & 0,197 \\
\hline Ukupno - Total & 81 & 1,23 & 5,87 & 8 & 0,01 & 0,06 & 5 & 0,01 & 0,03 & 94 & 1,25 & 5,96 \\
\hline Po ha - Per ha & 1620 & 24,64 & 117,39 & 160 & 0,27 & 1,16 & 100 & 0,16 & 0,61 & 1880 & 25,07 & 119,16 \\
\hline \multicolumn{5}{|c|}{ Šumarija: Rab - Forest management: Rab } & \multicolumn{8}{|c|}{ Pokusna ploha: PP1 - Experimental plot: PP1 } \\
\hline \multicolumn{5}{|c|}{ Gospodarska jedinica: Kalifront - Management unit: Kalifront } & \multicolumn{8}{|c|}{ Površina: $40 \times 12,5 \mathrm{~m}\left(500 \mathrm{~m}^{2}\right)-$ Area: $40 \times 12,5 \mathrm{~m}\left(500 \mathrm{~m}^{2}\right)$} \\
\hline \multicolumn{5}{|c|}{ Odjel/odsjek: 10b - Department: 10b } & \multicolumn{8}{|c|}{ Godina: 9. 7. 2014. - Year: July 9, 2014} \\
\hline \multirow{2}{*}{$\begin{array}{l}\text { Deb. raz., cm } \\
\text { Diam. cl., cm }\end{array}$} & \multicolumn{3}{|c|}{ Quercus ilex } & \multicolumn{3}{|c|}{ Fraxinus ornus } & \multicolumn{3}{|c|}{ Arbutus unedo } & \multicolumn{3}{|c|}{ Ukupno - Total } \\
\hline & $\mathrm{N}$ & G & V & $\mathrm{N}$ & G & V & $\mathrm{N}$ & G & V & $\mathrm{N}$ & G & V \\
\hline 2 & & & & 1 & 0,001 & 0,003 & 3 & 0,002 & 0,005 & 4 & 0,002 & 0,008 \\
\hline 4 & 18 & 0,027 & 0,100 & 26 & 0,037 & 0,156 & 9 & 0,011 & 0,039 & 53 & 0,075 & 0,295 \\
\hline 6 & 9 & 0,022 & 0,089 & 3 & 0,007 & 0,031 & 4 & 0,010 & 0,033 & 16 & 0,039 & 0,153 \\
\hline 8 & 4 & 0,020 & 0,087 & & & & 1 & 0,005 & 0,024 & 5 & 0,025 & 0,111 \\
\hline 10 & 4 & 0,035 & 0,152 & & & & & & & 4 & 0,035 & 0,152 \\
\hline 12 & 18 & 0,203 & 0,966 & & & & & & & 18 & 0,203 & 0,966 \\
\hline 14 & 12 & 0,181 & 0,861 & & & & & & & 12 & 0,181 & 0,861 \\
\hline 16 & 18 & 0,380 & 1,778 & & & & & & & 18 & 0,380 & 1,778 \\
\hline 18 & 15 & 0,383 & 1,802 & & & & & & & 15 & 0,383 & 1,802 \\
\hline 20 & 6 & 0,191 & 0,940 & & & & & & & 6 & 0,191 & 0,940 \\
\hline 22 & 5 & 0,187 & 1,008 & & & & & & & 5 & 0,187 & 1,008 \\
\hline \multicolumn{13}{|l|}{24} \\
\hline 26 & 1 & 0,051 & 0,272 & & & & & & & 1 & 0,051 & 0,272 \\
\hline 28 & & & & & & & & & & & & \\
\hline 30 & 1 & 0,072 & 0,314 & & & & & & & 1 & 0,072 & 0,314 \\
\hline Ukupno - Total & 111 & 1,75 & 8,37 & 30 & 0,04 & 0,19 & 17 & 0,03 & 0,10 & 158 & 1,82 & 8,66 \\
\hline Po ha - Per ha & 2220 & 35,03 & 167,41 & 600 & 0,89 & 3,80 & 340 & 0,55 & 2,02 & 3160 & 36,48 & 173,23 \\
\hline
\end{tabular}




\section{Rasprava-Discussion}

Odnos prema šumama hrasta crnike, ali i prema sredozemnim šumama danas bismo trebali sagledavati u kontekstu dugotrajnoga antropogenoga utjecaja i postojeće strukture tih šuma (podjednak odnos državnih i šumoposjedničkih šuma u Hrvatskoj). U takvim uvjetima zahtjevno je uskladiti potrebe za stabilnošću i potrajnošću šumskoga ekosustava i potreba lokalnoga stanovništva u prvom redu za ogrjevnim drvom. Naravno, trebalo bi uzeti u obzir iskustva drugih sredozemnih zemalja posebno u gospodarenju panjačama. One su bitne u socijalnom i ekonomskom smislu jer osiguravaju velike potrebe za ogrjevnim i industrijskim drvom. U 2000. godini gospodarilo se s oko $16 \%$ šuma panjača u Europi koje su pokrivale 23 milijuna hektara (Nicolescu i dr. 2017). Prema podacima FAO-a (2007) i Eurostata (2015) u 28 zemalja Europske unije godišnje se izradi više od 100 milijuna kubnih metara ogrjevnoga drva. U svakom slučaju bilo koji oblik gospodarenja panjačama trebao bi za cilj imati potrajnost i osiguravanje proizvodne sposobnosti i zaštite tla (Scarascia-Mugnozza i dr. 2000). Iskustva u Grčkoj, u kojoj hrastove šume zauzimaju 1,5 milijun hektara, od te površine hrast crnika i hrast oštrika zauzimaju 470000 ha (Dafis i Kakouros 2006), otkrivaju samo nekoliko pokušaja prirodne obnove crnike iz sjemena (Ganatsas i dr. 2003). Nasuprot tomu nastoji se šumskouzgojnim zahvatima u panjačama proredama omogućiti konverziju uzgojnoga oblika. Prema nekim autorima (Hatzistathis i dr. 1996, Zagas i dr. 1998) radi se o slabim proredama (vadi se $10 \%$ od ukupnoga obujma), umjerenim proredama (vadi se $20 \%$ od ukupnoga obujma) i intenzivnim proredama (vadi se $30 \%$ od ukupnoga obujma). Najbolji su rezultati pokazani primjenom umjerenih proreda, koje su dobre i zbog veće otpornosti na širenje požara. Zahtjevnija je situacija primjerice $u$ zemljama i područjima gdje je još izraženiji pritisak na šume, kao što je Italija. La Marca i dr. (1995. i 1998) spominju da su u području Gargana uz Jadran na oko 10000 ha crnikovih panjača velike potrebe za ogrjevnim drvom. Stoga se panjačama gospodarilo u kratkim ophodnjama (15 godina), ali uz povremene požare i utjecaj stoke pogoršalo se stanje u kvalitativnom smislu. Za poboljšanje stanja postavljeni su pokusi za obnovu panjače, konverziju u visoki uzgojni oblik i ostavljanje prirodnoj sukcesiji. Rezultati su pokazali, uzimajući u obzir ekološki i ekonomski čimbenik, da je obnova panjača, ali u duljoj ophodnji, prihvatljivo rješenje, zatim konverzija u visoki uzgojni oblik (problem su veći troškovi i loši edafski uvjeti) i na kraju najmanje je prihvatljivo rje- šenje ostavljanje prirodnoj sukcesiji (La Marca i dr. 2008).

U našim rezultatima najopsežnija su istraživanja tijekom više desetljeća rađena na otoku Rabu, na zapadnom dijelu otoka (poluotok Kalifront) gdje prevladavaju šume hrasta crnike. Posljednja istraživanja i rezultati dobiveni analizom izmjere 2017. godine (na plohama u okviru projekta MAB) gotovo su jednaki Gaussovoj zvonolikoj krivulji koja je karakteristična za jednodobne sastojine (slika 6). Distribucije prsnih promjera sastojina unimodalne su, desno skošene, tipične za jednodobne sastojine (Pranjić i Lukić 1986). Uzrok smanjivanja broja stabala hrasta crnike i drugih vrsta nalazi se u unutarvrsnoj i međuvrsnoj kompeticiji za svjetlo i životni prostor kojega je sve manje kako se sastojina razvija. Ona poprima svoj oblik, zatvara sklop i stvara etaže u svojoj strukturi. U toj borbi jedinke koje su već osvojile povoljne uvjete za život tu prednost i zadržavaju, dok ostale fiziološki slabe i u konačnici odumiru. Jednom kada crnika zatvori sklop, sloja grmlja gotovo da nema. U kvalitativnom smislu bitno je istaknuti i potrebu radova na prorjeđivanju, što je vidljivo $u$ rezultatima u tablici 6 (Ljubić 2014). Većina grmolikih vrsta pronađena je na rubu sastojine, odnosno trajne pokusne plohe br. $36 \mathrm{u}$ uvjetima manje zasjene krošanja hrasta crnike i većega pristupa svjetlu. $S$ obzirom na dob sastojina i razdoblja izmjera razvoj sastojine na Mljetu (TPP br. 37) može se promatrati kao referentan za budući razvoj sastojine na Rabu, što je i vidljivo iz grafičkoga prikaza razvoja ukupnoga obujma na trajnim pokusnim plohama (slika 9). Sada kada je sastojina na Rabu znatno prirasla i kada se razvija u kvalitetniju panjaču, može se očekivati blaži prirast obujma. Iz prvih izmjera trajne pokusne plohe br. 36, koje datiraju iz 1983. godine, vidljivo je kako je tadašnja sastojina prema svom strukturnom obliku bila u stadiju makije. Izmjerom 1993. godine utvrđeno je da se sastojina postupno razvija u kvalitetnu panjaču. Iduća izmjera iz 2012. godine to i potvrđuje, a sastojina se dalje razvija, što potvrđuje posljednja izmjera. Preduvjet za navedeno je u skladu s istraživanjem Rauša i dr. (1994) koji navode da se šuma hrasta crnike ne smije sjeći u kratkim ophodnjama čistom sječom, već stručnim zahvatima treba provoditi radove na njezi i obnovi. Sustavna višegodišnja istraživanja (od 1997. godine) na trajnim pokusnim plohama opisana su u radovima Dubravca i Krejčija (2001), Krejčija i Dubravca (2000, 2004), Dubravca i Dekanića (2011), Dubravca i dr. (2018). Autori na 12 trajnih pokusnih ploha (tablica 4) istražuju strukturu sastojina hrasta crnike, a poseban je naglasak stavljen na mogućnost primjene principa oplodnih sječa, odnosno prevođenje 
panjača hrasta crnike u visoki uzgojni oblik. Važno je izdvojiti višegodišnja sustavna istraživanja na pokusnoj plohi broj 4 koja donose uspješne, praktične rezultate primjene oplodnih sječa, kojima je dobivena mlada sjemenjača hrasta crnike.

U kontekstu određenih šumskouzgojnih zahvata jedinstvena su istraživanja Hrvatskoga šumarskoga instituta (Dubravac i Krejči 2001, Krejči i Dubravac 2000, 2004) na području Šumarije Pula (tablica 4, plohe 4 i 5). Oplodnim je sječama uz sedmogodišnje pomladno razdoblje, pravilne i pravodobne višekratne radove na njezi mladoga naraštaja dobivena kvalitetna mlada sjemenjača hrasta crnike visokoga uzgojnoga oblika.

\section{Zaključak - Conclusion}

Na trajnim pokusnim plohama (plohe u okviru projekta MAB) izoliranima od antropogenoga utjecaja u tijeku su progresivni sukcescijski procesi. Samim time sastojina poprima izgled jednodobne sastojine, stabilna je i buduća istraživanja trebala bi pratiti daljnju dinamiku razvoja sastojine. Eventualni poremećaji mogli bi biti izazvani ponajviše požarom. Stoga su ključne opće mjere na zaštiti šuma od požara.

Od posebnih mjera svakako su šumskouzgojni radovi jer traže učinkovitu, pravodobnu te višekratnu njegu sastojine čišćenjem (već pod zastorom krošanja) uz zaštitu pomladne površine od divljači. Te su mjere u skladu s propisima koji vrijede u hrvatskom šumarstvu. Realno stanje u praksi ukazuje na različite stanišne uvjete, odnosno na velike površine degradacijskih oblika. Stoga bi trebalo intenzivnije razmatrati mjere kojima će se kvalitetno gospodariti panjačama. One su bitne jer samo prepuštanje progresivnoj sukcesiji iznimno je dug proces koji može biti zahvaćen i usporen požarima otvorenoga prostora. Također, potrebno je na nekim lokalitetima voditi računa o intenzivnom utjecaju divljači u lovištima (Cres - Punta Križa i Rab - Kalifront) jer prevelik broj divljači u dužem razdoblju negativno utječe na mlade biljke u šumskoj zajednici hrasta crnike i crnoga jasena. Uz taj izravni utjecaj antropogeni neizravni utjecaj sve više je prisutan u turističkoj djelatnosti jer je šumovitost i prirodnost pojedinih predjela bitna za rekreacije, ali i za moguće širenje turističke infrastrukture na šume i šumsko zemljište.

\section{Zahvala - Acknowledgement}

Na pomoći pri izmjerama pokusnih ploha te na obradi prikupljenih podataka zahvaljujemo studenticama i studentima Šumarskoga fakulteta Sveuči- lišta u Zagrebu tijekom preddiplomskoga i diplomskoga studija. Rezultat su njihova rada i diplomski radovi na Zavodu za ekologiju i uzgajanje šuma pod mentorstvom prof. dr. sc. Željka Španjola. Zahvala kolegicama Martini Kičić, mag. ing. silv., Sanji Končar, mag. ing. silv., Ivoni Rimac, mag. ing. silv., i kolegama Ivanu Ljubiću, mag. ing. silv., Ivici Mikuleku, mag. ing. silv., i Ivanu Šafraniću, mag. ing. silv.

\section{Literatura - References}

Balen, J., 1937: Drugi prilog poznavanju naših mediteranskih šuma. Šumarski list, 6(7-8): 345-446.

Barčić, D., Ž. Španjol, O. Antonić, 2000: Vegetation succesion on permanent plots in holm oak (Quercus ilex L.) forests in Croatia. Glasnik za šumske pokuse, 37: 133-143.

Bernetti, G., 1995: Selvicoltura speciale, UTET, Torino, $416 \mathrm{p}$.

Brusić, V., 1926: Otok Rab. Franjevački samostan sv. Eufemije, Rab, 196 str.

Dafis, S., P. Kakouros, 2006: Guidelines for the rehabilitation of degraded oak forests. Greek Biotope/Wetland Centre, Thermi, $40 \mathrm{p}$.

Dubravac, T., V. Krejči, 2001: Pojavnost mladog naraštaja u sačuvanim panjačama hrasta crnike (Quercus ilex L.) uvjet osiguranja budućih sjemenjača. U: Znanost u potrajnom gospodarenju hrvatskim šumama, S. Matić, A. P. B. Krpan, J. Gračan (ur.), Šumarski fakultet Sveučilišta u Zagrebu, Šumarski institut Jastrebarsko, »Hrvatske šume« p.o., Zagreb, 43-52.

Dubravac, T., V. Krejči, V. Viličić, D. Barčić, Ž. Španjol, 2009: Uloga i značaj šuma hrasta crnike (Quercus ilex L.) u očuvanju šumskih ekosustava Mediterana. U: Uloga i značaj šumskog sjemena u obnovi šuma - 50. obljetnica šumskog sjemenarstva u Republici Hrvatskoj 1959.-2009., M. Ivanković (ur.), Zagreb, 27-29.

Dubravac, T., S. Dekanić, 2011: Oplodnim sječama od panjače do sjemenjače hrasta crnike (Quercuus ilex L.) Rezultati višegodišnjeg praćenja obnove, rasta i razvoja mlade sjemenjače hrasta crnike na stalnoj pokusnoj plohi u Puli. Znanstveni skup: Šumarstvo i poljoprivreda hrvatskog sredozemlja na pragu Europske unije, Hrvatska akademija znanosti i umjetnosti, Znanstveno vijeće za poljoprivredu i šumarstvo, Znanstveno vijeće za zaštitu prirode, Split, 20-21.

Dubravac, T., D. Barčić, 2017: National perspectives on coppice from 35 EuroCoppice member countries. COST Action FP1301 Reports. Nicolescu, V.-N., Bartlett, D., Buckley, P., Rossney, D., Pyttel, P., Unrau, A. (eds), Albert Ludwig University of Freiburg, Germany, 88 p.

Dubravac, T., M. Turk, D. Barčić, 2018: Konverzija panjača hrasta crnike (Quercus ilex L.) oplodnim sječama - rezultati višegodišnjih znanstvenih istraživanja. U: Poljopri- 
vreda i šumarstvo na kršu mediteransko-submediteranskog istočnojadranskog područja - stanje i perspektive, knjiga 27, T. Šarić, V. Beus (ur.), Sarajevo, 103-121.

EUROSTAT, 2015: Roundwood, fuelwood and other basic products [Online]. Available: http://ec.europa.eu/eurostat/web/main/home.

FAO, 2007: State of the world's forests 2007 (accessed 14-112015) http:// www.fao.org/docrep/009/a0773e/a0773e00. HTM; 2007.

Ganatsas, P., M. Tsakaldimi, T. Tsitsoni, 2003: Using oak species in reforestation projects in Greece. Proceedings of $11^{\text {th }}$ Panhellenic Forest Science Conference, Ancient Olympia, Hellenic Forestry Society, 126-132.

Hatzistathis A., T. Zagas, P. Gkanatsas, T. Tsitsoni, 1996: Thinning treatment effects on stand structure and quality of holm oak coppice. Proceedings of second Balkan scientific conference on Study, Conservation and Utilisation of Forest Resources, 1: 11-16, Sofia.

Houghton, J. T., Y. Ding, D. J. Griggs, M. Noguer, P. J. van der Linden, X. Dai, K. Maskell, C. A. Johnson (eds), IPCC, 2001, Climate Change 2001: The scientific basis. contribution of working group I. Third assessment report of intergovernmental panel on climate change. Cambridge University Press, Cambridge.

Ibañez, J. J., M. J. Lledó, J. R. Sánchez, F. Rodá, 1999: Stand atructure, aboveground biomass and production. In: Ecology of Mediterranean Evergreen Oak Forests, J. Bellot (ed.), Ecological Studies, Vol. 137, Springer-Verlag, Berlin - Heidelberg, 31-45.

Javna ustanova za upravljanje zaštićenim dijelovima prirode »Priroda« Primorsko-goranske županije: (https:// ju-priroda.hr/zasticena-podrucja-pgz/suma-dundo/) (6. 5. 2020)

Krejči, V., T. Dubravac, 2000: Obnova panjača hrasta crnike (Quercus ilex L.) oplodnom sječom. Šumarski list, 124(11-12): 661-668.

Krejči, V., T. Dubravac, 2001: Mogućnost obnove šuma nacionalnih parkova. Radovi Šumarskoga instituta, 36(2): 113-122.

Krejči, V., T. Dubravac, 2004: Oplodnom sječom od panjače do sjemenjače hrasta crnike (Qurcus ilex L.). Šumarski list, 128(7-8): 405-412.

La Marca, O., P. A. Marziliano, N. Moretti N., G. Pignatti, 1995: Dinamica strutturale e floristica in un ceduo di leccio. Annali Accademia Italiana di Scienze Forestali, 34: 235-256.

La Marca, O., P. A. Marziliano, A. Santoro, 1998: Management in ageing holm oak (Quercus ilex L.) coppices: experimental results after four growing seasson. Annali Istituto Sperimentale Selvicoltura, 27: 161-166.

La Marca, O., P. A., Marziliano, D., Scopigno, 2008: Opzioni selvicolturali su cedui di leccio del Gargano: risulta- ti a 14 anni dall'avvio della sperimentazione. Foresta, 5: 318-336. https://doi.org/10.3832/efor0552-0050318

Lasman, D., 1906: Šumarenje na otoku Rabu. Šumarski list, 30(4): 138-163.

Ljubić, I., 2014: Utjecaj proreda na pomlađivanje u panjačama hrasta crnike (Quercus ilex L.) na otoku Rabu. Diplomski rad, Šumarski fakultet Sveučilišta u Zagrebu.

Matić, S., 1985: Prevođenje makija i panjača hrasta crnike u sastojine visokog uzgojnog oblika. Savjetovanje »Gospodarenje šumama mediteranskog područja Rab«, Rab.

Matić, S., 1987: Gospodarski zahvati u panjačama kao mjera povećanja produktivnosti i stabilnosti šuma. Šumarski list, 111 (3-4): 143-147.

Matić, S., Đ. Rauš, 1986: Prevođenje makija i panjača hrasta crnike u sastojine višeg uzgojnog oblika. Glasnik za šumske pokuse, posebno izdanje, 2: 79-86.

Nicolescu, V.-N., J. Carvalho, E. Hochbichler, V. Bruckman, M. Piqué-Nicolau, C. Hernea, H. Viana, P. Štochlová, M. Ertekin, M. Tijardovic, T. Dubravac, K. Vandekerkhove, P. D. Kofman, D. Rossney, A. Unrau, 2017: Silvicultural guidelines for European coppice forests. COST Action FP1301 Reports. Albert Ludwig University of Freiburg, Germany, 32 p.

Petračić, A., 1938: Zimzelene šume otoka Raba. Glasnik za šumske pokuse, 6: 3-60.

Pravilnik o uređivanju šuma, Narodne novine, 52/1994.

Ogaya, R., J. Peńuelas, 2003: Comparative field study of Quercus ilex and Phillyrea latifolia: photosynthetic response to experimental drought conditions. Environmental and Experimental Botany, 50: 137-148. https://doi.org/10.1016/ S0098-8472(03)00019-4

Piškorić, O., 1963: Dinamika visinskog prirasta izbojaka iz panjeva česmine (Quercus ilex L.). Šumarski list, 87(3-4): 122-133.

Plieninger, T., J. Modolell y Mainou, W. Konold, 2004: Land manager attitudes toward management, regeneration, and conservation of Spanish holm oak savannas (dehesas). Landscape and Urban Planning, 66: 185-198. https://doi.org/10.1016/S0169-2046(03)00100-2

Pranjić, A., N. Lukić, 1986: Oblični broj i dvoulazne tablice volumena crnike (Quercus ilex L.). Glasnik za šumske pokuse, posebno izdanje, 2: 169-177.

Rauš, Đ., S. Matić, 1984: Sinekološko-uzgojno istraživanje u šumama otoka Raba. Šumarski list, 108 (3-4): 131-145.

Rauš, Đ., J. Vukelić, 1994: Program za gospodarenje šumama Nastavno-pokusnoga šumskog objekta Rab 19862005. Glasnik za šumske pokuse, 30: 421-443.

Rauš, Đ., J. Vukelić, Ž. Španjol, T. Đuričić, 1994: Istraživanje sukcesije crnikovih šuma na trajnoj pokusnoj plohi (br. 36) na Rabu. Glasnik za šumske pokuse, 31: 93-134.

Scarascia-Mugnozza G, H. Oswald, P, Piussi, K. Radoglou, 2000: Forests of the Mediterranean region: gaps 
in knowledge and research needs. Forest Ecology and Management, 132: 97-109. https://doi.org/10.1016/S03781127(00)00383-2

Stajić, B., T. Zlatanov, T. Dubravac, P. Trajkov, 2009: Past and recent coppice forest management in some regions of South Eastern Europe. Silva Balcanica, 10(1): 9-19.

Šafar, J., 1963: Uzgajanje šuma. Savez šumarskih društava Hrvatske, Zagreb, 598 str.

Šafar, J., B. Dereta, 1968: Melioracija i rekonstrukcija izdanačkih šuma. Radovi Šumarskoga instituta, 9: 1-199.

Španjol, Ž., 1995: Prirodna obilježja Raba. Barbat, Rab Zagreb, 429 str.
Šumskogospodarska osnova područja Republike Hrvatske za razdoblje 2016-2025. Hrvatske šume d.o.o., Zagreb 2016.

Šurić, S., 1933: Opis i osnova gospodarenja u državnoj šumi Dundo na otoku Rabu. Šumarski list, 57(3): 259-265.

Vacca, A., F. Aru, G. Olesch, 2016: Short-term impact of coppice management on soil in a Quercus ilex L. stand of Sardinia. Land Degradatoin and Development, 28: 553565. https://doi.org/10.1002/ldr.2551

Zagas, T., P. Gkanatsas, T. Tsitsoni, A. Hatzistathis, 1998: Influence of silvicultural treatment on ecology, quality and fire resistance in Quercus ilex coppice stands. In: N. Greece. Proceedings of VII International Congress of Ecology (INTECOL), 19-25 July 1988, Florence, Italy, 473 p.

\section{Abstract}

\section{Stand Structure Research in Holm Oak Forests (Quercus ilex L.) on Experimental Plots in Croatia}

The role of holm oak forests is not primarily commercial, though they have some commercial uses (heating wood, biomass). Today, under conditions of climate change, the ecological and social roles of these forests are becoming increasingly important, particularly since this species is predominantly found in low forest forms (coppices). In the Republic of Croatia, the surface area of holm oak coppices is 21,216.63 ha, of which 8351.79 ha are under the regular management of the national company Hrvatske šume d.o.o. (Croatian Forests). Another 12,740.18 ha are within privately owned forests. Holm oak coppices are characterised by a lack of any silvicultural works during the young stages of the forest and during their development, despite the fact that silvicultural works, such as cleaning, thinning and restoration, are prescribed for coppices. Since they are left to develop spontaneously, an entire spectrum of wood is produced, from relatively high wood stock with well formed and sufficiently thick stands, to lesser quality, sparse forms with poor, weak trees of low wood volume. This study was conducted on MAB plots (Man and Biosphere international project) of the Faculty of Foresty, University of Zagreb, and plots of the Forestry Institute. Structural research was conducted in holm oak forests, and compared to permanent experimental plots (PEP) on the islands of Rab, Brijuni and Mljet (PEP nos. 36, 56 and 57, 37, respectively). Comparison with other PEPs (Fig. 9) on the Brijuni Islands and Mljet Island, where the association Fraxino orni-Quercetum ilicis H-ić is also present, gives a broad overview of the succession of this community. Since there was only one measurement for PEP No. 57 (Brijuni Islands), the initial comparison refers to measurements on PEPs No. 36 (Rab Island) and 37 (Mljet Island). Systematic research (ongoing since 1996) on the PEPS is outlined in the studies of Dubravac and Krejci (Tables 4 and 5). The authors examined 12 PEPs and described the structure of holm oak stands therein, with special emphasis on the possibility of applying seed cutting, or transforming holm oak coppices into high growth forest. Thinning experiments were conducted on the experimental plots of the Faculty of Forestry, University of Zagreb, in the period from 2006 to 2014 (results shown in Tables 7 and 8). Progressive succession processes were found to be underway on experimental plots that were isolated from anthropogenic influences. These stands took on a stable, middle-aged form, and future research should continue to monitor the dynamics of stand development. Possible disturbances are most likely to result from fire.

Keywords: holm oak coppice, monitoring, eu-mediterranean, conversion, growth dynamic 
Authors' addresses - Adrese autorâ:

Izv. prof. dr. sc. Damir Barčić ${ }^{\star}$ e-pošta: dbarcic@sumfak.hr Doc. dr. sc. Mario Ančić e-pošta:mancic@sumfak.hr Prof. dr. sc. Željko Španjol e-pošta: zespanjol.rab@gmail.com Sveučilište u Zagrebu Šumarski fakultet Svetošimunska 25 10000 Zagreb HRVATSKA

Dr. sc. Tomislav Dubravac e-pošta: tomod@sumins.hr Hrvatski šumarski institut Cvjetno naselje 41 10450 Jastrebarsko HRVATSKA

Petar Ćurić, univ. spec. šumarstva e-pošta: petar.curic@gmail.com Vojina Bakića 1 10000 Zagreb HRVATSKA

* Glavni autor - Corresponding author 